\title{
Research on the Reform Path of Comprehensive Administrative Law Enforcement System in Kunming
}

\author{
Li Kun \\ School of Public Finance and Management, \\ Yunnan University of Finance and Economics, Kunming, China
}

35233882@qq.com

\begin{abstract}
At present, with the tide that our country pushes forward the ruling country by law in depth and the reform of city law enforcement system, the reform of comprehensive administrative law enforcement in Kunming is also at a new crossroads. How to do well the next step reform has become a theoretical and practical problem that we must answer. This article takes the comprehensive administrative law enforcement of Kunming City as the research object, discusses its historical evolution, and analyzes its current status and existing problems in depth. It proposes that the law enforcement function should be further transformed and integrated, a scientific comprehensive administrative law enforcement system should be established, the law enforcement leadership system and coordination mechanism should be improved, a mechanism for sharing information on management and law enforcement should be established, and the law enforcement forces at the grassroots level should be constantly strengthened so as to continuously improve the reform measures of the efficiency of comprehensive administrative law enforcement.
\end{abstract}

Keywords-comprehensive administrative law enforcement; historical evolution; reform path

The reform of comprehensive administrative law enforcement system is not only a key measure to deepen the reform of administrative system, to construct a modern government responsibility system, to transform government functions and to promote the construction of a government ruled by law, but also a inevitable choice to strengthen and improve the city management and raise the production and living needs of the residents. The Third Plenary Session of the 18th Communist Party of China Central Committee and the Fourth Plenary Session of the 18th Communist Party of China Central Committee all proposed the reform goals of "deepening the reform of the administrative law enforcement system, advancing the integrated construction of a country under the rule of law, a government under the rule of law, and a society under the rule of law." In 2015, the Communist Party of China Central Committee and the State Council issued the Guiding Opinions on Further Promoting the Reform of city Law Enforcement System and Improving city Management Work, which makes clear the reform objective of "promoting Comprehensive Administrative Law Enforcement" and requires that "The emphasis shall be placed on the implementation of comprehensive law enforcement in areas that are closely related to the production and livelihood of the masses, where law enforcement is frequent, where the issue of long-term law enforcement nuisances is prominent, where professional technologies are required to be appropriate, and which are closely related to the management of the city and require the centralized exercise of the right to administrative penalties.' We should adhere to the lowering of the focus of law enforcement and clarify the main responsibilities of the municipal and county governments in city management and law enforcement. In accordance with the principle of consistent powers and responsibilities of the territorial management, a division of responsibilities of the city management departments shall be established scientifically and rationally. Based on the historical evolution and the basic situation of the reform of comprehensive administrative law enforcement system in Kunming in recent years, this paper analyzes the connotation and scope of promoting the reform of comprehensive administrative law enforcement, and puts forward some ideas and suggestions for improving and perfecting the comprehensive administrative law enforcement system by aiming at the existing problems in the field of administrative law enforcement in Kunming.

\section{I . The Connotation And Scope of the REForm of}

\section{COMPREHENSIVE ADMINISTRATIVE LAW ENFORCEMENT}

\section{A. The Connotation of Comprehensive Administrative Law}

\section{Enforcement}

Administrative law enforcement is an important way for administrative agencies to achieve governmental functions. It is an activity that administrative agencies carry out externally the affairs of management, economics and society in their own name within the limits of their statutory functions and powers according to the stipulations of the Constitution and the Law, and independently assume legal responsibilities and consequences. Administrative law enforcement is the most important form of government administration according to law. According to statistics, about $80 \%$ of Chinese laws, $90 \%$ of local laws and regulations, and almost all administrative laws and regulations are implemented by administrative agencies. Therefore, whether administrative law enforcement is 
scientific and reasonable reflects directly the ability and level of government at all levels to administer according to law.

For a long time, the controversy on the connotation and extension of administrative law enforcement has been continuously in the jurisprudential circle. Some scholars think that administrative law enforcement only refers to the administrative punishment. Some hold the view that administrative law enforcement means the administrative punishment, the administrative supervision and inspection, and then the administrative execution. Some scholars also put the administrative examination and approval under the category of administrative law enforcement. (1)Administrative law enforcement involves the diversity of the subject, covers a wide range of content, and its scope, standards and methods are difficult to form a unified understanding. In addition, the related research on the subject of administrative law is not deep enough, therefore there is also a phenomenon of pluralism in the understanding of its concept in the academic circle. In terms of this article, we believe that administrative law enforcement refers to the specific administrative act of the administrative subjects who conduct the comprehensive judgment on the compliance of the administrative counterparts with laws and regulations based on their statutory powers and then impose administrative penalties, administrative supervision and inspection, administrative coercion and other measures according to their illegal situations. For a long time, due to the law enforcement difficulties in the process of administrative law enforcement such as duplicate law enforcement, overlapping responsibilities, and ambiguity of power and duties, the administrative law enforcement agencies and competent departments have adopted law enforcement reforms such as joint law enforcement and the right to the relative concentration of administrative penalties to further improve administrative law enforcement activities. Comprehensive administrative enforcement came into being in this context. The so-called comprehensive administrative law enforcement refers that the local government at or above the county level (including the county level) integrates and consolidates the administrative law enforcement issues in the economic and social fields that have the characteristics of similarity, relevance and unity in accordance with the laws and regulations and reform documents issued by the state, and then adopt an administrative law enforcement model which is set up according to law or authorized by law to exercise the law enforcement power in a unified way. In short, it is a new administrative law enforcement system that sets up a new law enforcement subject according to law or authorizes an existing administrative organ to exercise the relevant law enforcement power in a unified way and to put an end to the duplicate law enforcement and the chaos of law enforcement.

\section{B. The Main Content and Scope of the Reform of}

\section{Comprehensive Administrative Law Enforcement}

The reform of comprehensive administrative law enforcement mainly takes integrating and standardizing the subject of law enforcement, relatively centralizing the right to administrative law enforcement, pushing down the focus of law enforcement, improving the law enforcement system at the grassroots level and promoting the innovation in the methods of the law enforcement supervision as the main content, and comprehensively promotes the reform of comprehensive law enforcement within departments and across departments, industries and regions. In short, the reform of comprehensive administrative law enforcement involves the unification of the right to administrative law enforcement, the integration of the subject of law enforcement, the improvement of the vertical and horizontal law enforcement organization system, the standardization of law enforcement procedures, the innovation of law enforcement methods, the improvement of comprehensive law enforcement protection mechanisms and other aspects. As far as the scope of comprehensive administrative law enforcement is concerned, the Decision on Several Major Issues Concerning Promoting the Rule of Law in An All-round Way of the Communist Party of China Central Committee clarifies the key areas for promoting comprehensive law enforcement, including mainly food and drug safety, industrial and commercial quality inspection, public health, production safety, cultural tourism, resources and environment, agriculture, forestry and water conservancy, transportation, city and rural construction, marine fishery and other fields. As far as the reform of the city law enforcement system is concerned, the Guidance Opinions of the Central Committee of the Communist Party of China on Promoting the Reform of city Law Enforcement System and Improving the city Management Work clearly stipulates the specific scope for advancing comprehensive law enforcement, including the right to administrative punishment and the related administrative coercion of housing construction in city and rural areas, environmental protection, business management, traffic management, water management, food and drug supervision, related administrative compulsion and other fields. Based on this, we believe that the areas and scope of our reform of comprehensive administrative law enforcement will be mainly covered: Comprehensive law enforcement in the field of agriculture, comprehensive law enforcement in the field of environmental protection, comprehensive law enforcement in the field of transportation, comprehensive law enforcement in the field of market supervision, comprehensive law enforcement in the field of city management, comprehensive law enforcement in the field of cultural and social undertakings and so on.

\section{II . AN ANALysis ON THE CURRENT Situation OF THE}

REFORM OF COMPREHENSIVE ADMINISTRATIVE LAW

\section{ENFORCEMENT IN KUNMING CITY}

\section{A. The Historical Evolution of the Reform of Comprehensive}

\section{Administrative Law Enforcement in Kunming City}

1) The Evolution of Comprehensive Administrative Law Enforcement Agencies in city Management

In order to deepen the reform of administrative management system and management methods, overcome the drawbacks of the traditional administrative law enforcement and improve the efficiency of administrative law enforcement, on December 18, 2008, Kunming City organized the "Kunming Municipal Bureau of Comprehensive Administrative Law Enforcement". It is a municipal government work unit, which is established at the county level and has three divisions within it. It works by cooperating with the Kunming Municipal Bureau of City Administration. It implements the management model that two agencies have one set of management models. (1)In November 2009, the Kunming Municipal Bureau of 
Comprehensive Administrative Law Enforcement and the Kunming Municipal Bureau of City Administration were revoked, and the Kunming Municipal Bureau of City Administration and Law Enforcement was established. They are mainly composed of Kunming Municipal Detachment of Comprehensive Administrative Law Enforcement, Kunming Municipal Office of Digital City Management, Kunming Municipal Center of Environmental Health Surveillance, Kunming Municipal Control Center of City Lighting, Kunming Municipal Logistics Service Center of the Kunming Municipal Bureau of City Administration and Law Enforcement. At the same time, in the 17 counties (districts) and development (vacation) parks of the city, in addition to the Dongchuan District where set up a comprehensive law enforcement team of city management by adding signs to the Ministry of Housing and Construction, other counties (districts) and development (vacation) parks have established the independent Bureau of City Administration and Law Enforcement.

The comprehensive law enforcement management model for city management is mainly based on the general requirements of "two-level government, three-level management, four-level network, lower center of gravity and higher-level supervision" to implement the hierarchical management framework of municipalities and districts that is "a combination of strips and blocks, but dominated by blocks". In terms of the function allocation, the Municipal Bureau is mainly responsible for the research and formulation of policies, regulations, and industry management standards and regulations for the comprehensive law enforcement of city management in the whole city; the supervision, guide and coordination of the comprehensive law enforcement work of city management in each county (district) and development (vacation) park; the management of the funds for comprehensive law enforcement of city management, and the participation of the preparation of the annual fund plan for comprehensive management of city management and the organization and the implementation of it; and the work of the unified supervision and command, overall coordination, supervision and inspection, and evaluation of digital city management in Kunming. The department of city administration and law enforcement of Each county (district, development (vacation) park) specifically undertakes the city administration and law enforcement work according to the territorial management principles.

2) The Reform Process of the Right to the Relative Concentration of Administrative Penalties

In July 2009, the Kunming City formulated the Stipulations on Comprehensive Administrative Law Enforcement of City Management in Kunming City, which establishes a comprehensive administrative law enforcement system for city management of "two-level government, three-level management, four-level network, lower center of gravity and higher-level supervision", clarifies the functions of municipal departments of comprehensive law enforcement: The functions is relatively concentrated on the exercise of 95 units or 411 articles of laws, regulations and rules exercised by the eight departments of city management, construction, planning, real estate, garden, municipal public utilities, industry and commerce, and traffic police. The content covers 9 functions and powers that include all or part of the power of administrative punishment in respect of city appearance and environmental sanitation management, construction management, planning management, garden greening management, municipal administration, real estate management, industrial and commercial administration, public security traffic management and other administrative enforcement powers entrusted by the municipal and county people's governments. At the same time, it also clarifies the cohesion problem of law enforcement functions between the Municipal Bureau of City Management and Law Enforcement and the municipal functional transfer departments such as construction, planning, real estate, garden, municipal public utilities, industry and commerce, traffic police and other departments. The departments of city management and law enforcement at the municipal and district level are the main bodies of administrative law enforcement and perform relatively centralized administrative punishments in the city management field.

In 2013, the Regulations on Comprehensive Administrative Law Enforcement of City Management of Kunming were formulated and issued, which further clarifies the scope of implementing administrative law enforcement by municipal departments of city management and law enforcement as follows: the scope is concerned about 81 units or 390 articles of laws, regulations and rules that include the all of the right to punishment in respect of city appearance and environmental sanitation management, afforest management, town and country planning, housing and urban-rural construction management and the part of the right to punishment in the area of industrial and commercial administration and road traffic management and other powers of punishment carried out by the department of city management and law enforcement and stipulated by the local laws and regulations of Kunming and the regulations of the municipal government.

3) The Reform of Comprehensive Law Enforcement System in the Field of Cultural Market and Environmental Protection

In the field of cultural market, the Kunming City has established a comprehensive law enforcement detachment for the cultural market to specifically undertake the law enforcement functions in the fields of publications, radio and television, and cultural and entertainment industries in the field of cultural market. The Examination Outline of Business Skill Training (Trial) of the comprehensive law enforcement detachment for the cultural market in Kunming City was issued to strengthen the quality of the law enforcement team. At the same time, the comprehensive law enforcement in the cultural market area was carried out at regular intervals and this has achieved certain results.

In the field of environmental protection, in order to implement the Regulations for the Protection of Dianchi in Yunnan Province and with the approval of the Provincial Government of Yunnan Provincial Committee, Kunming City has specifically established the Team of Law Enforcement of Kunming Dianchi Bureau of Comprehensive Administrative Management and Law Enforcement. The Law Enforcement Team authorized the career establishments for 46 persons and is responsible for the work of comprehensive administrative law enforcement of Dianchi including a total area of approximately 920 square kilometers in the Dianchi Basin, 35 rivers that enter the Dianchi and 84 tributary areas. The Law Enforcement Team consists of the Fisheries Department and the Marine Department. At the same time, the fishery and maritime departments are set up vertically in counties and districts under the jurisdiction of the district, and they are specifically responsible for the comprehensive law enforcement of Dianchi watershed management. 


\section{B. An Analysis on the Problems of Comprehensive}

\section{Administrative Law Enforcement in Kunming City}

\section{1) The Comprehensive Administrative Management} System is not smooth

At present, there are issues such as unclear responsibilities and blank management in some areas of comprehensive administrative law enforcement in Kunming City. In particular, the municipal departments were more involved in the specific work of comprehensive administrative law enforcement. They have not given full play to the functions of formulating norms and standards, guiding, supervising, inspecting and evaluating the work of comprehensive administrative law enforcement at the county (city) and district levels. The coexistence of work offside and vacancy appeared. Due to the poor implementation of the territorial management in all counties (cities) districts, the division of labor is prominent. Relative to the low cost of illegal activities, many problems of comprehensive administrative governance such as illegal construction, illegal discharge, and road occupation management have emerged. The absence of administrative law enforcement is very obvious.

Some of the enforcement powers of the comprehensive administrative law enforcement agencies come from the transfer of other departments. In the process of the transfer of departmental powers, due to the lack of the uniform standards and the effective legal protection, the internal structure of some newly formed comprehensive law enforcement agencies is unreasonable and difficult to integrate. The lack of scientific and rational definition and legitimacy of law enforcement content has directly affected the orderly development of the law enforcement work. For tasks that require the cooperation of relevant functional departments to complete, due to the lack of corresponding law enforcement coordination mechanisms between departments, the efficiency of administrative law enforcement is greatly affected.

2) The Weak Law Enforcement at the Grass-roots Level

In recent years, the work of comprehensive administrative law enforcement in Kunming City focuses on the main urban area, and the blind spot of this work is in the suburban area. There are fewer business contacts between the municipal departments of comprehensive administrative law enforcement and the suburban counties and departments of comprehensive administrative law enforcement. The funding support for municipal-level comprehensive administrative law enforcement is also mainly in the main city area. The lack of effective support to the work of comprehensive administrative law enforcement in suburban areas has led to a tendency to marginalize the work in rural areas. With the trend of marginalization, cities, districts (counties) only have cross-cutting issues on the illegal construction of rural housing. With the economic and social development, the responsibility for territorial management of townships (streets) and villages (neighborhood committees) in areas such as public security, ecological protection, city management, social management, livelihood cause and so on has become increasingly burdensome. However, at present, laws and regulations stipulate that the main body of administrative law enforcement is often government departments above the county level. In view of the problem that the management authority of the township (street) and village (neighborhood committee) does not adapt to the management task, it is mainly solved by the extending law enforcement agency or the manner in which law enforcement is entrusted. However, the legal consequences of entrusted law enforcement need to be borne by the entrusting agency. The inconsistency of the power and responsibility makes the subjects of law enforcement above the county level unwilling to devolve the law enforcement authority to the grassroots.

3) The Borders of the Authority and Responsibility for Approval, Supervision and Law Enforcement are Blurred

The promotion of comprehensive law enforcement and the establishment of comprehensive law enforcement agencies are in accordance with the requirements that the decision-making, enforcement, and supervision powers both restrict and coordinate each other. The relative separation of all management responsibilities performed by a government department over a field into approval, supervision and enforcement. This puts forward new requirements for clarifying the boundaries of the responsibilities of examination and approval, supervision, and law enforcement. In the practice of the reform of comprehensive law enforcement, due to various subjective and objective reasons, it is easy to blur the boundary of supervision and law enforcement so that three major problems appear: The first is that law enforcement is equal with supervision. Comprehensive law enforcement is the most effective means of supervision---The power of administrative punishment shall be stripped and recombined from the original management structure. Some departments will intentionally or unintentionally confuse this essential issue. When transferring the power of administrative punishment, the responsibility of supervision is transferred, and some or all of the administrative management is grafted to the agencies of comprehensive administrative law enforcement. Some departments even think that after the transfer of law enforcement powers, the original departments have been lack of the ability to grasp, and do not have to perform regulating functions. The second is to "cover the world" by the comprehensive law enforcement. Some departments and grass-roots governments have a vague understanding of the concept and boundary of comprehensive administrative law enforcement. It is considered that the administrative law enforcement is the end and most effective one. Most management problems can be solved through punishment, which weakens the role of prior management in practical work. Instead of taking the means of guidance and control from the forming stage or early stage of the conflict, it is hoped that the final solution will be through law enforcement. The third is that the convergence of "examination and approval-supervision-law enforcement" is not smooth. After the separate allocation of the duties of examination and approval, supervision, and law enforcement, the phenomenon of separatism, fragmentation, and "information isolated islands" also emerged. The effective linkage mechanism between departments is lack.

4) The Laws and Regulations are Complicated and Intersecting; The applicability of them is not high; The procedure is absent.

The current administrative and legal system of our country is relatively complex, and the level of laws and regulations is wide. Especially in the case of the department-led legislation, there are many cross-cutting and conflicting laws between different departments. Taking the city management of Kunming City as an example, in recent years, Kunming City has completed the legislative work of local regulations and government regulations such as Regulations on Comprehensive Administrative Law Enforcement of City Management in Kunming City, 
Administrative Measures on Waste from Restaurant Kitchens in Kunming City, Regulations on the Supervision of Comprehensive Administrative Law Enforcement in Kunming City, Regulations on the Administration of City Lighting in Kunming City and so on; The Kunming City revised local and government regulations such as Regulations on the Administration of City Roads in Kunming City, Regulations on the Administration of Outdoor Advertising in Kunming City, Regulations on City Appearance and Environmental Hygiene in Kunming City, Management Measures on Outdoor Advertising Facilities in Kunming City and so on. In terms of the quantity and coverage, the content of city comprehensive management is basically included, but its practicability or performance is often discounted. In particular, there are some problems such as overlapping and intersecting between laws and regulations, which produce a lot of trouble to the subject of law enforcement about how to apply the law in law enforcement activities.

\section{THE MEASURES TO PUSH FORWARD THE REFORM OF}

THE COMPREHENSIVE ADMINISTRATIVE EXECUTIVE LAW

\section{ENFORCEMENT SYSTEM IN KUNMING CITY}

\section{A. The further transformation and integration of the law}

enforcement functions, and the building of the scientific

and reasonable comprehensive administrative executive

law enforcement system

1) Clarify the field and scope of the comprehensive administrative executive law enforcement in accordance according to the law, and build the comprehensive administrative law enforcement organization system in the city, county and township levels

In recent years, there have been some outstanding achievements in the comprehensive law enforcement of the urban management, the market regulation and the land administrative law enforcement and other fields in Kunming city, partly solved such outstanding problems such as the overlapping of the administrative law enforcement agencies, repetition of multipoints and the cross law enforcement. In the future, we should focus on promoting the reform of the comprehensive administrative law enforcement from the comprehensive, systematic and holistic height. Under the premise of not violating the host law, we should fully prepare the comprehensive administrative law enforcement power list, responsibility list, further clarify the field and scope of the law enforcement, conduct the integration of the institutions' functions in a new round for the departments with the same functions of the law enforcement, the same objects of the law enforcement and the same ways of the law enforcement. According to the different levels of the government's functions and powers, we should rationally allocate the powers of the law enforcement, and reduce the levels and categories of the administrative law enforcement.

In the level of the administrative law enforcement organization system, we should focus on conducting the relatively concentrated reform of the law enforcement power in the comprehensive law enforcement of the urban management, comprehensive law enforcement of the environment protecting, comprehensive law enforcement of the social undertakings (culture), comprehensive law enforcement of the housing in the town and country construction, comprehensive law enforcement of the traffic, and the comprehensive law enforcement of the market supervision regulation. Through the ways such as the internal integration and integration of the agencies and so on, we should combine the functions and institutions of the law enforcement with the similar nature, object, process, and according to the actual situation of various fields, gradually build up the comprehensive law enforcement organization system in three-level of the city, county (district), villages and towns (street). The first one is to establish the comprehensive administrative law enforcement department as the department of the government in the municipal level, in charge of drafting the law enforcement regulations, implementing rules, etc., and giving the guidance and supervision for the comprehensive administrative law enforcement activities in the level of the county (district), villages and towns (street). The second one is to establish comprehensive administrative law enforcement team mainly in the level of the county (district), the villages and towns (street), including the comprehensive law enforcement team of the urban management, the comprehensive law enforcement team of the market supervision, the comprehensive law enforcement team of the environment protecting, the agricultural comprehensive law enforcement team, and the traffic comprehensive law enforcement team, and to distribute the enough personnel for the law enforcement team and to tamping the first-line law enforcement power at the grass-roots level. The third one is to, in the villages and towns (street) level, apply the agency pattern of the subject of the comprehensive administrative law enforcement in the county level to build the comprehensive administration team, and carry out the law enforcement activities in the reason of the authority in the county level, at the same time accept the leadership of the people's government in the same levels of the villages and towns (street), to ensure that the law enforcement activities can get the help and support from the government in the same level.

2) Actively building the law enforcement pattern of "a team in a field"

In 2014, the Yunnan provincial party committee and the provincial government formulated the Guidance on the Function Transformation and Institutional Reform of the Governments Under the Province Level"(launched by NO. 22 [2014] ), which clearly put forward:" in order to further promote the enforcement of center of gravity down, we should reduce the law enforcement level, integrate and optimize the law enforcement resources. The administrative law enforcement responsibility is mainly in charge of the county's government (city, district), and the administrative law enforcement team set up in the county level according to the principle of territoriality. Two administrative law enforcement teams in the same types are not set in the area of the same county government level." "The state (city) does generally not set up the special administrative law enforcement team". In 2015, the State Council of CPC central committee issued Guidance on Further Promoting the Reform of the City Law Enforcement System and Improve the Urban Management and it clearly puts forward that, we should reasonably divide the urban management duties, achieve the apanage management, and classify the subject's responsibility of the city and county government in the urban management and law enforcement. These host laws, regulations and government rules further define the comprehensive law enforcement power in the reinforcement of city and county, and establish the overall requirements of 
the comprehensive law enforcement team in every field.

As for the problems, Kunming city should continue to push and deepen the reform pilot of the relatively concentrated administrative punishment power according to the general requirements of the host law, further straighten out and distinguish the functions of the government sectors, promote the institutional restructuring and merger, forming the comprehensive agricultural law enforcement, comprehensive environmental law enforcement, comprehensive traffic law enforcement, the comprehensive law enforcement of the urban management, the comprehensive law enforcement of the market supervision and the comprehensive law enforcement of the social undertaking, build the new pattern of urban comprehensive administrative law enforcement of "big agriculture, big urban management, big market, big environmental protection, big transportation, big culture", and realize the law enforcement of "a team in a field".

\section{B. Perfect the leadership system of the law enforcement}

and coordination mechanism, and improve the efficiency

\section{of the comprehensive administrative law enforcement}

1) Build the leading institutions of the comprehensive administrative law enforcement in all the fields, and realize the effective link in the examination and approval, supervision and law enforcement

In the process of the reform of the urban comprehensive administrative law enforcement, Kunming city should establish the comprehensive administrative law enforcement leadership council by making the main leaders ((deputy) mayor, the (deputy) county mayor) of the governments as the group leaders and by making the heads of various functional departments as the members in the field of the comprehensive law enforcement, and set up the offices in the comprehensive law enforcement departments, to ensure that the comprehensive reform of administrative law enforcement can have the strong leadership in all areas, to enhance the harmony and cooperation of the various functional departments in the process of the reform. Establish the comprehensive law enforcement leadership council in every field mainly leading by the government, can effectively prevent the various functional departments transferring the functions of law enforcement with the nature of "baggage" to the comprehensive law enforcement by the various reasons, in the transferring of the law enforcement power, and retain law enforcement functions with the nature of "interest", then it will lead to the executive power transferring, incomplete entrusting, and happen the dilemma in the overlapping of the law enforcement and cross law enforcement in a new round. In addition, in the process of law enforcement, the comprehensive administrative law enforcement departments need the coordination and cooperation of all various functional departments, mainly including the information of the administrative licensing (approval) and recording, the information and data mastered by the functional departments performing the regulating functions, etc., and set up the sound and thorough public administration and the law enforcement information sharing mechanism. It needs a higher level's lead agency to plan and coordinate so that it can effectively enhance the comprehensive administrative law enforcement efficiency. In the case of the city management comprehensive administrative law enforcement in the Kunming city, we should set up comprehensive administrative law enforcement committee by the mayor or deputy mayor as the team leader to enhance the systematicness, integrality and cooperative of the comprehensive administrative law enforcement of city management, by overall planning the work coordination of the city management comprehensive administrative law enforcement department and the public security department, the housing construction department and the environmental protection department.

2) Classify clearly the boundaries between the law enforcement power and administration power, and ravel out the relationship between the law enforcement function and administration function

The administrative law enforcement power not only includes the administrative punishment power, but also includes the right of administrative inspection and the supervision right, etc. As a result, in the process of the reform of the comprehensive administrative law enforcement in all areas in Kunming city, we further clarify the boundaries between the management authority of the functional departments and the law enforcement power of the law enforcement departments, and make their respective scope clear, to ensure that each performs its own functions and responsibilities, especially to put an end to the bad phenomenon that some functional departments make use of the management authority to implement the administrative law enforcement authority. It causes to the damage of the administrative relative persons' rights and interests, such as the impact on the relative persons' rights and interests caused by the administrative guidance as the reason.

3 ) Strengthen the effective cohesion of the public security, procuratorate, court and other departments in the administrative law enforcement process, and build the linkage mechanism of the administrative law enforcement

The urban comprehensive administrative law enforcement is a complex systematic project. The punishment for the administrative illegal activities not only involves the subjects of the comprehensive administrative law enforcement in various fields, but also often needs the strong cooperation of the public security organs, procuratorial organs, judicial organs and other departments. For example, the urban management law enforcement involves the public security detention, violent resistance against law, etc., which needs to get involved by the police security; the environmental protection law enforcement involves the environmental public interest litigation which needs to transfer the procuratorial organs, etc. As a result, in the process of the reform of the comprehensive administrative law enforcement in all areas in Kunming city, we combine the characteristics and nature of the comprehensive law enforcement, strengthen the effective connection of the public security, procuratorates, courts and other judicial organs in the law enforcement process, build the linkage mechanism between the comprehensive administrative law enforcement departments and the judicial departments, and improve the legitimacy and effectiveness of the comprehensive administrative law enforcement. The first one is to implement to have a respective leader crossly holding the urban management comprehensive administrative law enforcement department and the public security department, and set up the public security detachment in the urban management department at the county level; The second one is to coordinate to establish the linkage mechanism of the urban management law enforcement, the public security organs, procuratorial organs, courts and judicial organs; the third one is to establish and improve the transfer mechanism of the 
environmental protection comprehensive administrative law enforcement organs and the public interests litigation cases of the procuratorial organs.

\section{Establish the sharing mechanism of the management}

law enforcement information, and constantly strengthen the law enforcement power at the grass-roots level

1) Strengthen the intelligent information platform construction of the urban comprehensive management

In recent years, the local governments at all levels in our country are trying to promote the e-government information system construction, establish the comprehensive governance information system platform, to achieve the e-government information resources sharing. Build the wisdom city comprehensive management service platform plays an important role in the building of the government information system for the current government entities at all levels in some developed areas. In the process of the reform of the urban comprehensive administrative law enforcement, Kunming city also should focus on promoting the construction of the government affairs information system comprehensive management platform, further optimize and integrate the information system of public security, the mayor's hotline system, the digital urban management information platform, and environmental health detection system, etc,. It can use for reference the successful experience of the developed eastern provinces to build the smart city comprehensive management information service platform of Kunming city, and set up the digital urban management subsystem, socially comprehensive management subsystem, emergency command subsystem, community correction supervision subsystem, ecological safety supervision subsystem, public place supervision subsystem and safe production supervision subsystem, etc. By integrating the information resource platforms of the departments, we can build the comprehensive information interaction platform of Kunming city, achieve the inter-connectivity of the city management information data resources, get through the "information isolated island" among the departments, and further improve the efficiency of the urban management and comprehensive law enforcement.

2) Integrate the existing law enforcement power, and enrich the law enforcement team in the primary level

At present, there is a total of 834 for the special manning quotas of the comprehensive administrative law enforcement in Kunming city, including 58 for the municipal city management comprehensive administrative law enforcement organs, and the rest manning quotas are allocated to the county (district) law enforcement departments, it should be said that this is basically in line with the basic ideas and general requirements for strengthening the construction of the county (district) law enforcement power in the national leadership and Yunnan province. However, there are still some outstanding problems in the weak of the administrative law enforcement team in Kunming city. In the future, we should further strengthen the construction of the power of the county (district), villages and towns (street) administrative law enforcement team. The first one is, by establishing a new pattern "big agriculture, big urban management, big market, big environmental protection, big transportation, big culture" of the urban comprehensive administrative law enforcement as an opportunity, through the integration of the law enforcement powers in various areas and various functional departments, tend to transfer the special manning quotas of the law enforcement in various fields into the comprehensive administrative law enforcement team in the county (district), villages and towns (street); The second one is to, by making the dynamic adjustment mechanism reform in Kunming city as an opportunity, enrich the actual number of the manning quotas for the comprehensive administrative law enforcement in all fields, put an end to the phenomenon that law enforcement team staff are seconded by the related departments. The third one is to intensify the construction of the quality of the administrative law enforcement team, actively implement the administrative law enforcement system of the employment with certificates through the ways of the pre-job training and on-the-job training, make efforts to improve the overall quality of the personnel of the administrative law enforcement team in the county (district), villages and towns (street), continuously improve its resumption abilities and law enforcement level, to strengthen the quality's construction of the law enforcement team and to improve the efficiency of the comprehensive administrative law enforcement in the primary level.

3) Intensify the assistance, auxiliary power construction of the administrative law enforcement in the way of the government purchasing the public service

At present, with the acceleration of urbanization, the urban area has a rapid population growth in the city of Kunming, the downtown area expands unceasingly, and the urban internal management comprehensive affairs generally increases and gradually complicated. These has brought a huge challenge for the city management in the comprehensive administrative law enforcement in various fields, especially, the interdisciplinary and cross-regional enforcement cases generally increase. The existing urban management comprehensive administrative law enforcement team obviously has a weak power, which becomes important bottleneck of the scientization and ordering of the city management comprehensive administrative law enforcement. For this reason, in view of the dilemma that the manning quotas of the comprehensive administrative law enforcement are short and its law enforcement is weak, we think that we can, by innovating the mode of government purchasing the public service as an opportunity, promote the administrative law enforcement government to purchase the public services, in the way of purchasing the assistants' labor and services of the administrative law enforcement by the financial funds, such as the traffic management assistant, environmental protecting assistant, river management coordinator, city management coordinator and the market supervision assistant, push forward the construction of the assistance and auxiliary power of the administrative law enforcement, at the same time, improve the admittance threshold of the government purchasing the labors, make efforts to improve their comprehensive qualities, to strengthen the construction of the comprehensive administrative law enforcement power in various areas in Kunming city through the help of the government buying the public services.

\section{REFERENCES :}

[1] The State Council of CPC central committee, The Decisions on Some Important Problems in Promoting the Rule by Law. The People's Daily,2014-10-29 (01) . (in Chinese)

[2] The State Council of CPC central committee, Guidance on Further Promoting the Reform of the City Law Enforcement System and Improve the Urban Management. The People's Daily, 2015-12-31( 03). (in Chinese)

[3] Yuan Shuhong. Deepen the administrative law enforcement system reform. The People's Daily, 2013-11-27 (02) . (in Chinese) 